\title{
British Studies
}

\section{Liberty, Retrenchment and Reform}

Popular Liberalism in the Age of Gladstone, 1860-1880

Eugenio F. Biagini

In an innovative synthesis of the history of popular support for the Liberal party, the author shows that, like republicanism or socialism in continental Europe, liberalism in Britain was a mass movement. This book examines the people who supported it, their beliefs, and the way in which those beliefs related to one another and to reality. 40315-4 Hardcover $\$ 74.95$

\section{Virtue Transformed}

Political Argument in England, 1688-1740

\section{Shelley Burtt}

This book offers a detailed study of political argument in early eighteenth century England. The author not only challenges the received notions of the fortunes of virtue in the early modern era but provides a promising critical perspective on the question of what sort of politics of virtue is possible or desirable today. 37528-2 Hardcover $\$ 39.95$

\section{Merchant Enterprise in Britain}

From the Industrial Revolution to World War I

\section{Stanley Chapman}

This survey of the mercantile sector of the economy concentrates the various ways in which British merchants responded to the unprecedented opportunities of the Industrial Revolution and the growth of the British Empire.

35178-2 Hardcover $\$ 69.95$
After Nature

English Kinship in the Late

Twentieth Century

Marilyn Strathern

Central as kinship has been to the development of British social anthropology, this is the first attempt by an anthropologist to situate ideas about English kinship in a cultural context. The author challenges the traditional separation of Western kinship studies from the study of the wider society.

Lewis Henry Morgan Lectures 40525-4 Hardcover $\$ 54.95$ 42680-4 Paper $\$ 19.95$

\section{National Crisis and National Government}

British Politics, the Economy and

Empire, 1926-1932

\section{Philip Williamson}

This book is the first to examine all aspects of the crisis together and in depth using an extensive range of official, institutional and personal papers. It demonstrates that a proper understanding of economic and imperial policies requires a sophisticated grasp of political processes. 36137-0 Hardcover $\$ 89.95$

\section{The British Electorate, 1963-1987}

A Compendium of Data from the British Election Studies

Ivor Crewe, Neil Day and Anthony Fox

This book provides for the first time an authoritative reference guide to British voters and British elections. It is based on a wealth of statistical information collected over the past quarter century by the British Election Study research teams at the Universities of Oxford and Essex.

32197-2 Hardcover $\$ 160.00$ 


\section{From Cambridge}

\section{The Spirit of the} Oxford Movement

Tractarian Essays

Owen Chadwick

"...the collection is interesting to read. The author is a great scholar and a superb writer."

-Catbolic Historical Review

In this collection of new and revised essays the author writes on various aspects of the Oxford Movement and the English Church in the Victorian era. 37487-1 Hardcover $\$ 59.95$ 42440-2 Paper $\$ 19.95$

\section{William Cobbett and Rural Popular Culture} lan Dyck

This first book-length study of the rural and cultural career of the great English countryman William Cobbett (1763-1835) uses Cobbett's own writings as well as innovative sources such as popular rural songs and ties Cobbett's radical politics to the countryside. 41394-X Hardcover $\$ 59.95$

\section{Friends in Life and Death}

British and Irish Quakers, 1650-1900

\section{Richard T. Vann and David Eversley}

This volume looks at patterns of child-bearing, marriage and death among more than 8,000 Quaker families during the period of demographic transition. The authors show how high fertility and high mortality were features of English Quaker life, to be succeeded after 1825 by a move towards the modern, small family. Cambridge Studies in Population, Economy and Society in Past Time 17 39201-2 Hardcover $\$ 49.50$

\section{The Revolution of 1688-89}

Changing Perspectives Lois G. Schwoerer, Editor

These essays help advance recent "changing perspectives" on the Revolution of 1688-89 by offering novel and interdisciplinary interpretations of the Revolution and of the late Stuart and early Hanoverian world from both an international and a domestic English perspective.

Contributors: Stephen B. Baxter, J. M. Beattie, Karl S. Bottigbeimer, Gary S. De Krey, Jack P. Greene, K. H. D. Haley, Bruce P. Lenman, Howard Nenner, J. G. A. Pocock, Lois Potter, Jobn C. Rule, Gordon J. Scbocbet, Lois C. Schwoerer, W. A. Speck, Rachel J. Weil, Steven N. Zwicker. 39321-3 Hardcover $\$ 59.95$

\section{The London Hanged}

Crime and Civil Society in the Eighteenth Century Peter Linebaugh

"This is a bold, sweeping and provocative book. At its core is an analysis of 1,242 persons publicly hanged at Tyburn between 1703 and $1772 \ldots$. This is a book that will make for much fertile argument among specialists, while for the general reader it offers the most engrossing and stirring slice of London's history to have appeared in a long time. In the age of the bland, the commitment, passion and humanity of this dynamic book recommend it to readers well beyond the ranks of professional historians."

-The Times Higher Education Supplement 41842-9 Hardcover $\$ 44.95$ 


\section{British Studies}

\section{The Radical}

\section{Reformation}

Michael G. Baylor, Editor

This book is a collection of writings by early Reformation radicals that illustrates both the diversity and the areas of agreement in their political thinking. Cambridge Texts in the History of Political Thought

37073-6 Hardcover $\$ 44.50$

37948-2 Paper $\$ 14.95$

\section{Locality and Polity}

A Study of Warwickshire Landed Society, 1401-1499

\section{Christine Carpenter}

This is a comprehensive study of minor landowners - the gentry in one county of fifteenthcentury England. It looks at all aspects of their lives, including marriage, the family, how they ran their estates and how they made friends and enemies, in an often very turbulent century. 37016-7 Hardcover $\$ 125.00$

\section{The Pillars of}

\section{Priestcraft Shaken}

The Church of England and its Enemies, 1660-1730

\section{J. A. I. Champion}

The author is concerned with the radical Republican attacks on Christianity in England between 1660 and 1730 and the origins of the early English Enlightenment. Far from interpreting this attack as a secular or rational movement, he argues for the religious aspirations of the reformers and emphasizes the English contribution to ideas that have been associated traditionally with the French Enlightenment.
English and French Towns in Feudal Society

A Contemporary Study

R. H. Hilton

This is a comparative study of the role of English and French towns in feudal society in the Middle Ages. Professor Hilton challenges the view that "a town is a town wherever it is," and takes issue with the perception of the medieval town as the harbinger of capitalism.

Past and Present Publications 41352-4 Hardcover $\$ 44.95$

\section{The First Crusade}

\section{Steven Runciman}

"It reads magnificently. As an example of sustained and intelligent narrative it could hardly be bettered. Sir Steven's great achievement was to make a complicated subject appear simple and then to write it up beautifully..." A Canto Book

42705-3 Paper $\$ 9.95$

\section{Richard Price: Political Writings \\ D. O. Thomas, Editor}

Richard Price (1723-1791) was an eminent Welsh philosopher and Dissenting Minister who won considerable fame as a supporter of the American and French Revolutions. The volume is comprised of his most important pamphlets (1759-1789).

Cambridge Texts in the History of Political Thought

40162-3 Hardcover $\$ 49.95$

40969-1 Paper $\$ 16.95$ 


\section{From Cambridge}

A Main Selection of the

History Book Club

Mr. Bligh's Bad

Language

Passion, Power, and Theater

on the Bounty

\section{Greg Dening}

"Greg Dening has produced a powerful new account of an event that has, over two centuries, helped to define our modern understandings of tyranny and resistance. His tale about Bligh and the mutineers is imaginative and learned, engaging and entertaining, much to be enjoyed by anyone interested in the society and culture of wooden ships and iron men." - -Marcus Rediker, Georgetown University 38370-6 Hardcover $\$ 34.95$

\section{The Paintings of Thomas Gainsborough} Malcolm Cormack

This unique up-to-date and perceptive survey shows that Gainsborough was more than the well-known painter of The Blue Boy and the perennial rival to Joshua Reynolds. 38241-6 Hardcover $\$ 40.00$

\section{English Portrait}

\section{Miniatures}

Revised Edition

\section{Graham Reynolds}

The first edition of this general survey on the art of portrait miniatures became the standard work on the subject. In this thoroughly revised edition, the author has entirely rewritten the early chapters to take account of recent research and has made corrections and revisions throughout. 33920-0 Paper $\$ 29.95$

\section{Hailey}

A Study in British Imperialism, 1872-1969

John W. Cell

William Malcolm Hailey (18721969) was by common consent the most distinguished member of the Indian Civil Service in the twentieth century. This is the first booklength study of Hailey's career. 41107-6 Hardcover $\$ 47.95$

\section{The English Rural Community}

Image and Analysis

Brian Short, Editor

An inter-disciplinary perspective on the realities that lie behind the myths and images of rural England is offered by examining such central issues as development, migration, labor patterns, religious practice and the rural labor force.

40537-8 Hardcover $\$ 59.95$

Friends in Life and Death

British and Irish Quakers, 1650-1900

Richard T. Vann, David Eversley

This volume looks at patterns of child-bearing, marriage and death among more than 8,000 Quaker families. Comparisons are drawn throughout with the general population, other elite groups and the Irish Quakers.

Cambridge Studies in Population, Economy and Society in Past Time 17 $39201-2$ Hardcover $\$ 49.50$

Available in bookstores or from

\section{CAMBRIDGE UNIVERSITY PRESS}

40 W. 20th St., N.Y., NY 10011-4211

Call toll-free 800-872-7423

MasterCard/NISA accepted.

Prices subject to change. 




THE RESULT...

- History in an Interdisciplinary Framework

- The History of Art, Literature and the Social Sciences

- Reflections upon Historical Method and Forms of Inquiry

- A Long Tradition in the History of Mentalities and Representation

- Exploration of the Terrain Where Religion and History Meet

\section{RECENT ARTICLES INCLUDE:}

Linda Mitchell The Lady is a Lord: Noble Widows and Land in Tbirteenth-Century Britain

Paul Costello William McNeill's Ecological Mytbhistory

Philip Soergel Spiritual Medicine for Heretical Poison: The Propagandistic Use of Legends in Counter-Reformation Bavaria

Henry Clark Unmasking in the Political Culture of the French Revolution

William Cassidy Dionysos, Ecstasy, and the Forbidden

Patrick Hutton The Foucault Pbenomenon and Contemporary French Historiograpby

HR/RH appears three times with an annual subscription rate of $\$ 42$ for institutions and $\$ 24$ for individuals.

Send inquiries to The Editor

HISTORICAL REFLECTIONS/REFLEXIONS HISTORIQUES

Division of Human Studies

Kanakadea Hall

Alfred University

Alfred, NY 14802 


\section{BRITISH STUDIES FROM BLACKWELL}

Britain AND EUROPEAN CoOperation Since 1945 SEAN GREENWOOD

Historical Association Studies

November $1992 \quad 128$ pages

0-631-176543 paper

$0-631-181083$ cloth

$\$ 12.95$

\#34.95

\section{BRITAIN IN THE 1930's} ANDREW THORPE

Historical Association Studies April 1992128 pages 0-631-17411-7 paper 0-631-18047.8 cloth

\section{THE BRITISH ECONOMY}

\section{SINCE 1945}

Economic Policy and Performance, $1945-90$

ALEC CAIRNCROSS

Making Contemporary Britain

March $1992 \quad 320$ pages

0-631-18276-4 cloth

$\$ 9.95$

\section{WOMEN IN BritaIN}

Women, Family, Work and the State Since 1945

JANE LEWIS

Making Contemporary Britain

February $1992 \quad 152$ pages

$0-631.169768$ paper

0-631-16975-X cloth
$\$ 14.95$

$\$ 39.95$
Colonial America

A History, 1607-1760

RICHARD MIDDLETON

September $1992 \quad 436$ pages

J-55786-259-I paper

I-55786-258-3 clath

$\$ 54.95$

Social Change in CONTEMPORARY BRITAIN Edited by NICHOLAS ABERCROMBIE \& ALAN WARDE

A Polity Press Book April 1992 200 pages

a7456-0783-7 paper

0.7456-0782.9 clath \$39.95

\section{BLACKWELL HISTORY OF MUSIC IN BRITAIN}

Volume 3: The Seventeenth Century Edited by IAN SPINK

Blachwell History of Music

December $1992 \quad 300$ pages

a-631-16518 cloth

5100

\section{CONTEMPORARY BRITAIN}

An Annual Review 1992

Edited by PETER CATTERALL

June 1992

484 pages

$0.631-18494-5$ cloth

$\$ 74.95$ 




Edited by R.J.W. Evans and J.R. Maddicott

First published in 1886, The English Historical Review is the oldest quarterly journal of historical scholarship in the English-speaking world.

It deals with all aspects of European and world history, as well as the history of Britain itself, since the classical era.

The English Historical Review includes articles, 'Notes and Documents', and Debates on medieval and modern themes, as well as book reviews and a summary of international periodical literature.

\section{FREE SAMPLE ISSUE...}

Why not look at the journal with no obligation? To obtain a FREE recent issue, simply complete the coupon below and return to:

Judy Higgins, LHE, Longman House, Burnt Mill, Harlow, Essex CM20 2JE, UK. 


\section{AVAILABLE IN A QUILL TRADE PAPERBACK EDITION}

\section{Our Tempestuous Day}

A History of Regency England By Carolly Erickson

\section{Author of Bloody Mary and Mistress Anne}

"With wit and unerring evenhandedness, Miss Erickson brings [George IV] and his contemporaries to vibrant life."

- The New York Times Book Review

\section{OUR \\ TEMPESTUOUS DAY}

A History of Regency England

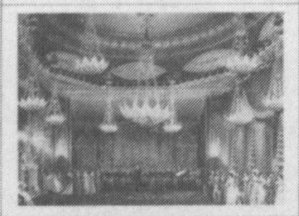

Carolly Erickson

$0-688-07292-5 \cdot \$ 8.95$

304 pages - Paperback

Illustrated • Notes

Bibliography • Index
"A sustained sense of a nation in troubled transition, poised uneasily between a powdered-wig coarseness and Victorian priggishness, between feudal privilege and a rising radicalism."

\section{- San Francisco Examiner}

"The pleasures of the book are such to appeal to the student or general reader....Anyone wanting a lively, decorative introduction to the Regency could not do better than Our Tempestuous Day."

— Lady Elizabeth Longford, The Washington Post Book World

\section{Special Offer - Free Examination Copy}

William Morrow will provide a free copy of Our Tempestuous Day to professors who are considering it for adoption. Please return the coupon to the address below, along with $\$ 1.50$ postage and handling. Your check or money order must be made payable to "William Morrow."

$\begin{array}{ll}\text { Name } & \text { Title } \\ \text { School } & \text { Department }\end{array}$

Address

Course No. Course Name Enrollment

Amount Enclosed 


\section{Copies of articles from this publication are now available from UMI Article Clearinghouse.}

For more information about the Clearinghouse, please fill out and mail back the coupon below.

The UMI Article Clearinghouse offers articles from more than 11,000 copyright-cleared periodicals in a wide range of subjects. You can place your orders electronically, as well as by phone, mail, and telefacsimile. For more information, please complete and mail this coupon to UMI Article Clearinghouse, 300 North Zeeb Road, Box 11, Ann Arbor, MI 48106 USA. Or call tollfree for an immediate response: 800-521-0600. From Alaska and Michigan call collect 313-761-4700. From Canada, call toll-free 800-343-5299.

YES! I'd like to know more about UMI Article Clearinghouse.

Name

Title

Company/Institution

Address

City/State/Zip

Telephone (

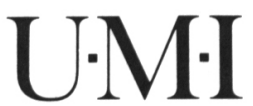

A Bell \& Howell Company 300 North Zeeb Road Ann Arbor, MI 48106 USA 


\section{ICTORIAN}

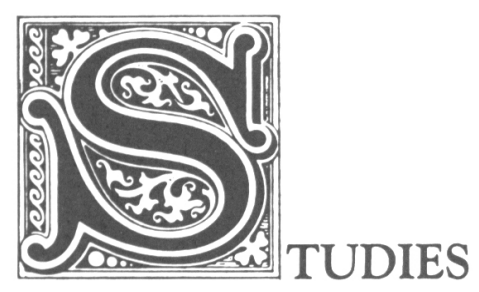

forthcoming in 1991-92

"The Uses of Romanticism: Byron and the Victorian Continental Tour," by James Buzard

"Felix Holt, the Killer: A Reconstruction," by Judith Wilt

"Homeward Bound: Dialect Domesticity and Working-Class Women Writers," by Susan Zlotnick

"Sex, Lies, and Printed Cloth: Bookselling at the Bodley Head in the 1890 s," by Margaret $D$. Stetz

"Climates of Opinion: Acclimatization in Nineteenth-Century France and England," by Warwick Anderson

"Robert Browning's 'Fra Lippo Lippi' and the Problematic of a Male Poetic," by Herbert Sussman 


\section{CHICAGO}

A Vindication of Political Virtue

The Political Theory of

Mary Wollstonecraft

Virginia Sapiro

Sapiro shows that Wollstonecraft's ideas about women's rights, feminism, and gender are elements of a broad and fully developed philosophy, one with significant implications for contemporary democratic and liberal theory.

Paper \$16.95 394 pages

Library cloth edition $\$ 53.00$
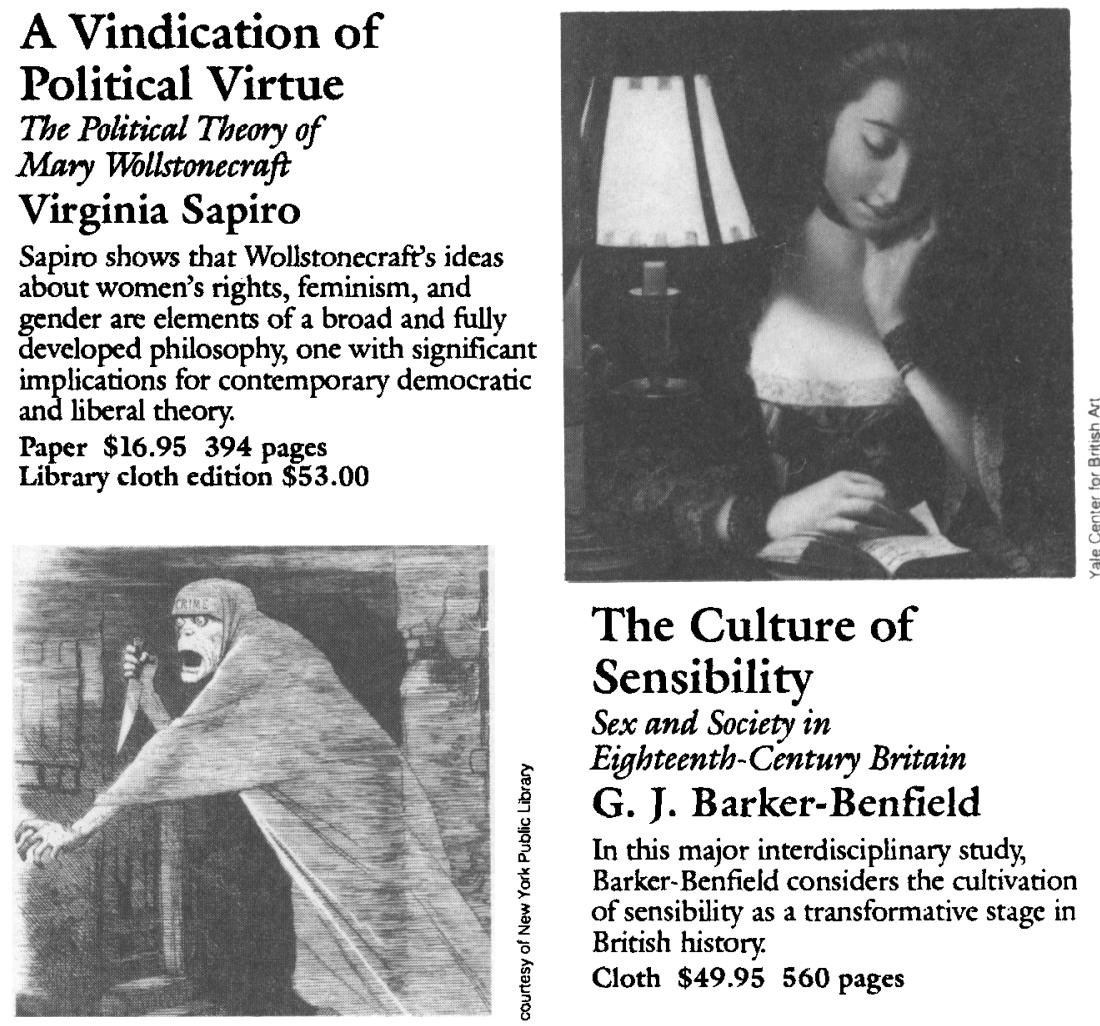

\section{The Culture of} Sensibility

Sex and Society in

Eighteenth-Century Britain

G. J. Barker-Benfield

In this major interdisciplinary study, Barker-Benfield considers the cultivation of sensibility as a transformative stage in British history.

Cloth $\$ 49.95560$ pages

\section{City of Dreadful}

\section{Delight}

Narratives of Sexual Danger

in Late-Victorian London

Judith R. Walkowitz

With a foreword by Catharine R. Stimpson

"This remarkably polished, lucidly argued, long awaited work is innovative cultural history at its best." - Martha Vicinus, University of Michigan

Paper $\$ 15.95382$ pages 15 halftones

Library cloth edition $\$ 35.00$

Women in Culture and Society series

\section{The University of Chicago Press}

5801 S. Ellis Ave., Chicago, IL 60637 


\section{The Imaginary Puritan}

Literature, Intellectual Labor, and the Origins of Personal Life NANCY ARMSTRONG and LEONARD TENNENHOUSE

"A tour de force that reconceptualizes literary history and repositions British literature to claim the imperial and trans-Atlantic origins of the British novel. Pathbreaking, provocative, The Imaginary Puritan must beread by literary critics, theorists, and historians."

-Carroll Smith-Rosenberg, author of Disorderly Conduct The New Historicism: Studies in Cultural Poetics $\$ 35.00$ cloth

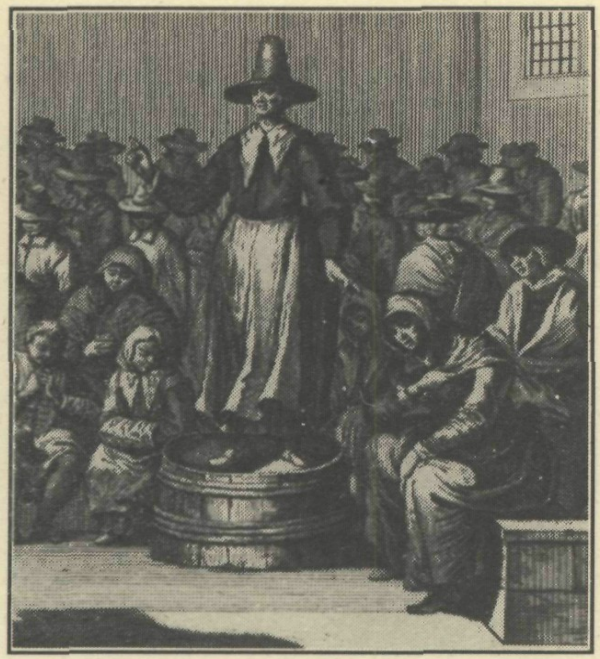

\section{Faultlines}

Cultural Materialism and the Politics of Dissident Reading ALAN SINFIELD

New historicism has often shown people trapped in a web of language and culture. In lively discussions of writings by Shakespeare, Marlowe, Sidney, and Donne, Sinfield reassesses the scope of dissidence and control.

"An important and urgently needed contribution to the field of culture criticism both in the U. K. and in the U.S.A." -Michael D. Bristol, author of Shakespeare's America, America's Shakespeare $\$ 48.00$ cloth, $\$ 19.00$ paper

\section{Visionary Women}

Ecstatic Prophecy in

Seventeenth-Century England PHYLLIS MACK

"A magnificent piece of original research and writing. I know of no one else who has brought as much intelligence or subtlety of argument to the general topic of Quaker women. Scholars await this book."

- Jean R. Soderlund, author of Quakers and Slavery

$\$ 40.00$ cloth

At bookstores or order toll-free 1-800-822-6657.

\section{University of California Press}

Berkeley Los Angeles New York Oxford 


\section{New in paperback}

\section{The Cambridge Cultural History of Britain}

Boris Ford, Editor

This nine-volume series presents a survey of the art, architecture, literature and music of Britain from prehistoric times through present day. Each volume includes an introductory chapter that offers a cultural and social backdrop to the period followed by illustrated chapters written by well known specialists. Originally published in hardcover as The Cambridge Guide to the Arts of Britain.

\section{Early Britain}

Includes: Beowulf, The Dream of the Rood, Stonehenge, Hadrian's Wall, Roman mosaics, the Sutton Hoo treasure, illuminated manuscripts. 42881-5 \$19.95 Paper

\section{Medieval Britain}

Includes: Royal patronage, a dominant Church, Chaucer, the Gawain poet, Wells Cathedral, Medieval Mystery Plays, plainchant, minstrelsy. 42882-3 \$19.95 Paper

\section{6th Century Britain}

Includes: The dissolution of the monasteries, Protestant humanism, Erasmus, More, Spenser, Marlowe, Shakespeare.

42883-1 \$19.95 Paper

\section{7th Century Britain}

Includes: The Civil War, the Great Fire of London, Milton, the Metaphysical Poets, Newton, Locke, Jacobean tragedy, Restoration comedy. 42884-X '\$19.95 Paper

Available in bookstores or from

\section{8th Century Britain}

Includes: Social Harmony, Pope, Gainsborough, Reynolds, Addison and Steele's Spectator, Swift, Hogarth. 42885-8 \$19.95 Paper

\section{The Romantic Age in Britain}

Includes: Industrialization, scientific discovery, Blake, Wordsworth, Coleridge, Austen, Turner, Constable, Nash, Academy of Music. 42886-6 \$19.95 Paper

\section{Victorian Britain}

Includes: the Great Exhibition, Williàm Morris, the pre-Raphaelites, Dickens, George Eliot, Ruskin; Elgar, Delius.

42887-4,\$19.95 Paper

\section{Early 20th Century Britain}

Includes: World Wars, the General Strike, Bloomsbury, Lawrence, Joyce, Lutyens, Holst, radio, film. 42888-2 \$19.95 Paper

\section{Modern Britain}

Includes: Tom Stoppard, Doris Lessing, the Beatles, Henry Moore, Graham Sutherland, radio, television, film. 42889-0 \$19.95 Paper 